\title{
Abdominal Pseudocyst: A Rare Complication of Ventriculoperitoneal Shunting
}

\author{
Faisal', Ridha Dharmajaya ${ }^{2}$, Muhammad Ihsan Z Tala ${ }^{3}$, Abdurrahman \\ Mousa Arsyad ${ }^{4}$, and Steven Tandean \\ ${ }^{12,3,4,5}$ Department of Neurosurgery, Faculty of Medicine, Universitas Sumatera Utara
}

\begin{abstract}
Ventriculoperitoneal (VP) shunt placement is one of the most commonly performed procedures in neurosurgery. One rare complication is the formation of an abdominal pseudocyst, which can cause shunt malfunction.
\end{abstract}

Keyword: Abdominal Pseudocyst, Ventriculoperitoneal Shunt

Abstrak. Ventriculoperitoneal (VP) shunt adalah salah satu prosedur yang paling sering dilakukan di bidang bedah saraf. Salah satu komplikasinya adalah pembentukan pseudokista abdominal, yang dapat menyebabkan malfungsi shunt.

Kata Kunci: Abdominal Pseudocyst, Ventriculoperitoneal Shunt

Received [2 Nov 2019] | Revised [28 Nov 2019] | Accepted [30 Nov 2019]

\section{Introduction}

Ventriculoperitoneal (VP) shunting is the preferred and most successful method for managing hydrocephalus. Abdominal complications include peritonitis, ascites, bowel and abdominal wall perforation and inguinal hernias. An uncommon but recognized complication is an abdominal pseudocyst (APC), with cerebrospinal fluid (CSF) collecting and being poorly or not absorbed across the serosa. This results in an increased pressure within the APC, reducing forward pressure gradient and optimal shunt function.[1]

The clinical presentation may resemble that of an acute abdomen: Abdominal pain with/without a palpable mass, abdominal distension with/without tenderness, nausea and/or vomiting, decreased appetite, constipation, fever and signs of shunt malfunction such as lethargy and headache. The term pseudocyst implies that the cyst is surrounded by a wall of nonepithelial tissue, such as intestinal serosa and peritoneum. The wall may have evolved from an inflammatory reaction to a focal peritonitis or low-grade infection. An increase in CSF protein

\footnotetext{
*Corresponding author at: faisalcoffee@gmail.com

E-mail address: faisalcoffee@gmail.com
} 
contents may also contribute to a sterile inflammatory response. Central nervous system malignancies such as astrocytomas and primitive neuroectodermal tumors have also been thought to predispose the abdomen to the development of an APC.

\section{Case Report}

A 6 year-old girl had undergone a ventriculoperitoneal shunt for hydrocephalus. She presented with confusion, abdominal distension and vomiting. She also complained of abdominal pain. The shunt had been inserted when aged a few months and had been revised in 8 month-old, with no sign of infection. Abdominal ultrasound scan showed a large fluid density collection extending on the left upper quadran abdomen.

The patient had surgical treatment options include excision of cyst and repositioning the distal peritoneal catheter in a different abdominal quadrant. Our patient did not have any signs or symptoms of infection. Analysis of CSF cultures, cell count, protein and glucose concentration were all normal. The formation of the APC may represent a non-infectious peritoneal reaction, associated with a chronic inflammatory process that is poorly understood. The unique feature of the presented case is the delayed presentation with an acute abdomen five years after the last shunt revision. In addition, despite the extreme sized APC, the patient did not present with a shunt malfunction or signs of raised intracranial pressure.

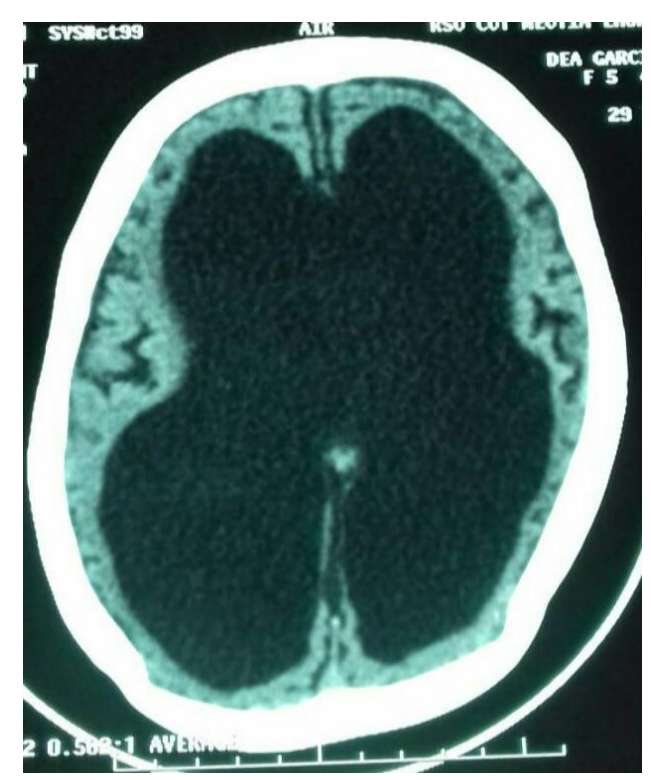

Figure 1. Head CT-Scan show enlarge ventricle 


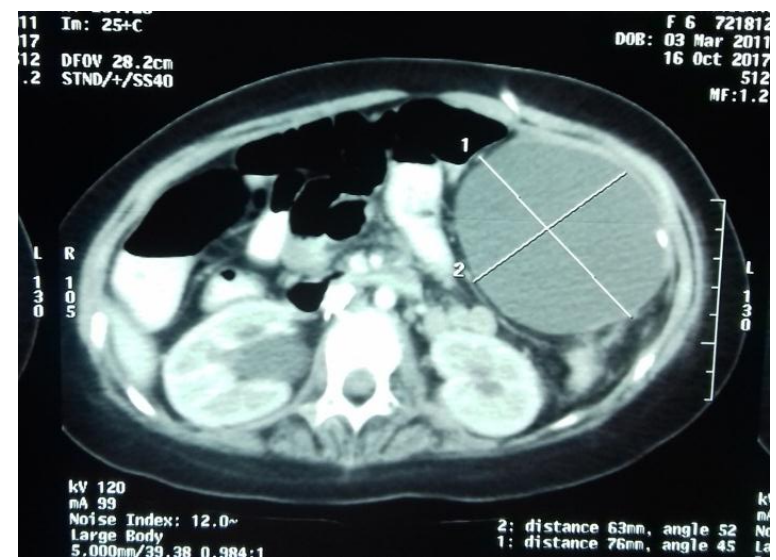

Figure 2. CT Abdomen, show cyst on left abdomen

\section{Discussion}

APC represents an uncommon complication of VP shunts of unknown aetiology in most cases. It may also present as an acute abdomen. Factors that contribute to decreased CSF absorption include shunt infection, previous abdominal surgeries or multiple shunt revisions.

Our patient did not have any signs or symptoms of infection. Analysis of CSF cultures, cell count, protein and glucose concentration were all normal. The formation of the APC may represent a non-infectious peritoneal reaction, associated with a chronic inflammatory process that is poorly understood. The unique feature of the presented case is the delayed presentation with an acute abdomen nine years after the last shunt revision. In addition, despite the extreme sized APC, the patient did not present with a shunt malfunction or signs of raised intracranial pressure.

\section{Conclusion}

APC represents an uncommon complication of VP shunts of unknown aetiology in most cases. It may also present as an acute abdomen. Factors that contribute to decreased CSF absorption include shunt infection, previous abdominal surgeries or multiple shunt revisions.

\section{REFERENCES}

[1] Agha FP, Amendola MA, Shirazi KK, Amendola BE, Chandler WF. Unusual abdominal complications of ventriculo-peritoneal shunts. Radiology. 1983;146:323-6.

[2] Arnell K, Olsen L. Distal catheter obstruction from non-infectious cause in ventriculoperitoneal shunted children. Eur J Pediatr Surg. 2004;14:245-9.

[3] Bryant MS, Bremer AM, Tepas JJ, 3rd, Mollitt DL, Nquyen TQ, Talbert JL. Abdominal complications of ventriculoperitoneal shunts. Case reports and review of the literature. Am Surg. 1988;54:50-5.

[4] Chuang VP, Fried AM, Oliff M, Ellis GT, Sachatello CR. Abdominal CSF pseudocyst secondary to ventriculoperitoneal shunt: Diagnosis by computed tomography in two cases. J Comput Assist Tomogr. 1978;2:88-91. 
[5] Coley BD, Shiels WE, 2nd, Elton S, Murakami JW, Hogan MJ. Sonographically guided aspiration of cerebrospinal fluid pseudocysts in children and adolescents. AJR Am J Roentgenol. 2004;183:1507-10.

[6] Davidson RI, Lingley JF. Intraperitoneal pseudocyst: Treatment by aspiration. Surg Neurol. 1975;4:33-6.

[7] de Oliveira RS, Barbosa A, Vicente YA, Machado HR. An alternative approach for management of abdominal cerebrospinal fluid pseudocysts in children. Childs Nerv Syst. 2007;23:85-90.

[8] Egelhoff J, Babcock DS, McLaurin R. Cerebrospinal fluid pseudocysts: Sonographic appearance and clinical management. Pediatr Neurosci. 1985;12:80-6.

[9] Ersahin Y, Mutluer S, Tekeli G. Abdominal cerebrospinal fluid pseudocysts. Childs Nerv Syst. 1996;12:755-8.

[10] Fischer EG, Shillito J., Jr Large abdominal cysts: A complication of peritoneal shunts. Report of three cases. J Neurosurg. 1969;31:441-4.

[11] Fried AM, Adams WE, Jr, Ellis GT, Hatfield DR, Walsh JW. Ventriculoperitoneal shunt function: Evaluation by sonography. AJR Am J Roentgenol. 1980;134:96770.

[12] Frykberg T, Olden L. Infection as a cause of peritoneal catheter dysfunction in ventriculo-peritoneal shunting in children. Z Kinderchir. 1983;38:84-6.

[13] Narasimharao KL, Purohit A, Yadav K, Pathak IC. Recurrent abdominal pseudocyst after ventriculoperitoneal shunt. Aust Paediatr J. 1984;20:73-4.

[14] Roitberg BZ, Tomita T, McLone DG. Abdominal cerebrospinal fluid pseudocyst: A complication of ventriculoperitoneal shunt in children. Pediatr Neurosurg. 1998;29:267-73. 